\title{
Lean Manufacturing Implementation through DMAIC Approach: A Case Study in the Automotive Industry
}

DOI: $10.12776 /$ QIP.V25I2.1576

\author{
Hanane Rifqi, Abdellah Zamma, Souad B. Souda, Mohamed Hansali
}

Received: 2021-05-20 Accepted: 2021-07-16 Published: 2021-07-31

\begin{abstract}
Purpose: The main objective of this paper is to validate the results of the Lean manufacturing application via the DMAIC concept. This study concerns a case study carried out in an automotive company which aims at improving its flows within the production workshop by pulling the physical flow and minimizing the different wastes.
\end{abstract}

Methodology/Approach: By conducting a literature review to examine the different frameworks for applying the lean method and to extract case studies related to the DMAIC approach which is missing on the selected articles, only one article that addresses this possibility.

Findings: DMAIC has allowed a better structuring of the entire project, choosing the right improvement solutions with the right choice of Lean tools and several advantages that are not valid for other frameworks. This implementation shows a spectacular improvement in the production planning, the fluidity of the flow as well as an important financial gain for the company.

Research Limitation/Implication: The project duration was not sufficient to apply other beneficial lean tools as the study was limited only to a single production line.

Originality/Value of paper: This article demonstrates the added value of the structured DMAIC approach to lean manufacturing methodology and implementation.

Category: Case study

Keywords: lean manufacturing; DMAIC; lean tools; automotive; case study 


\section{INTRODUCTION}

Lean manufacturing, Lean production, Lean institute, Lean office and other names always refer to the Lean concept which aims to eliminate activities and actions with no added value. The Lean concept is originated from Toyota production system TPS, invented to eliminate all types of waste in the production process of the Toyota company (Shingō and Dillon, 1989; Pech and Vaněček, 2018).

The word Lean appears for the first time in the famous book "the machine that changed the world" of Womack, Jones and Roos (1991), which defines it as: "Lean gives you the ability to produce more by using less - less human effort, equipment, time and space, while at the same time getting closer to the objective, which is to meet the exact need of the costumer" (Womack, Jones and Roos, 1991).

This paper has studied the good practices used by Toyota to overcome their crisis. Today, Lean manufacturing is applied in all countries and sectors either alone or by integrating it with other approaches such as six sigma, the agile model or the industry 4.0 (Marodin et al., 2019).

By applying lean manufacturing principles, many manufacturing industries around the world have reduced the cost of their products during the manufacturing phase and increased their profits (Vamsi Krishna Jasti and Sharma, 2014). This effect is witnessed by the literature where hundreds of successful case studies have been uncovered in all industries and especially in growing companies.

This document presents a relevant Lean Manufacturing application, implemented by following the systematic steps of the DMAIC approach to reduce the various waste forms that involve a high inventory of work-in-process for the company with a very complex workflow. In order to successfully implement the Lean concept, the team used a plethora of Lean tools Kaizen, Kanban, value stream mapping, 5S, Kaizen Team, Heijunka, Standardized Work, Takt time and Visual Control as well as many diagnostic tools such as Ishikawa, QQOQCCP, 5 whys, $5 \mathrm{M}$ and Pareto diagram where these tools were carefully chosen.

For the paper's organization, we will start with a literature review concerning Lean Manufacturing and its applicability as well as the DMAIC cycle. The second part will be focusing on the host company and its activities as well as the reasons for choosing and implementing Lean Manufacturing as a tool. All the DMAIC phases will be presented in the third part. The fourth part will include the gain generated and the Lean application's efficiency in this company. A conclusion and some perspectives will be discussed in the last part. 


\section{LITERATURE REVIEW}

\subsection{Lean Concept}

The Lean philosophy is the art of reduction and elimination of all non-value added activities, those activities that are known by Mudas in lean's jargon. The implementation of Lean production allows production with less human effort in the factory, less financial resources, less space and less equipment to manufacture the same product (Salonitis and Tsinopoulos, 2016). Toyota, the creator of Lean, depicted its philosophy as a temple to define the bases of Lean project construction and the pillars that reinforce its rigidity (see Figure 1). Each part of the temple enables to define the methodology's objectives with the elements on which it is necessary to act and the tools to be deployed.

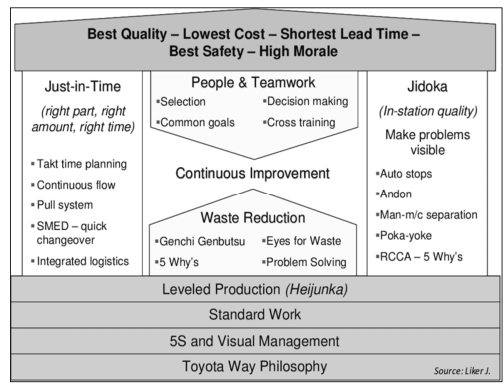

Figure 1 - Toyota Production System TPS (Rüttimann in Stöckli, 2016)

In order to successfully implement Lean, companies must follow the principles of Lean implementation, five generic principles are described in several books and articles (Jerry, 2003; Liker, 2004; Andersson, Eriksson and Torstensson, 2006; Su, Chiang and Chang, 2006; Rifqi, Ben Souda and Zamma, 2020, p.4) (see Table 1).

\subsection{Lean Manufacturing Implementation}

The Lean concept was first implemented in the automotive sector, its effective and successful application made a group of companies adopt it and take advantage of its benefits concerning waste reduction and flow optimization.

The applicability of lean thinking has been proven in the literature by hundreds of successful case studies, such as in banking sector (Hidayati, Tarigan and Tarigan, 2019), construction ( $\mathrm{Li}$, Fang and $\mathrm{Wu}, 2020$ ), pharmaceuticals 
(Sieckmann et al., 2018), electronics (Nguyen and Do, 2016), services (Piercy and Rich, 2009), metallurgy (Ching, Hoe, Hong, Ghobakhloo, in Pin, 2015), shipbuilding (Sharma and Gandhi, 2017), health (Régis, Santos and Gohr, 2019), as well as its implementation in universities (Balzer et al., 2016) where all these sectors have demonstrated the applicability and adaptability of the Lean concept.

\section{Table 1 - Lean Manufacturing Principles}

\begin{tabular}{|l|l|l|}
\hline Principle No. 1 & Value Stream & Identify the value from the customer perspective \\
\hline Principle No. 2 & value stream mapping & Identify value-added and non-value-added activities. \\
\hline Principle No. 3 & Continuous Flow & Create a continuous flow without waste \\
\hline Principle No. 4 & Pull system & Produce only what is needed and when it is needed. \\
\hline Principle No. 5 & $\begin{array}{l}\text { Perfection / continuous } \\
\text { improvement }\end{array}$ & Striving for perfection \\
\hline
\end{tabular}

Its implementation has also been linked and integrated with other concepts, services or paradigms. The Lean Sigma (Mostafa, Chileshe and Abdelhamid, 2016) is an example of an integrated concept where Lean focuses on efficiency and speed, it ensures that resources are well used and create value and on the other side the concept Six Sigma which seeks accuracy and precision by doing things right the first time. Also Lean logistics (Wronka, 2017) where Lean is applied in logistics service, it supports internal and external logistical processes to ensure a continuous flow of production materials and deliveries on time, in the right place, at the right quality and at the right cost. Several more concepts are created with the aim of strengthening Lean or to improve other concepts and approaches through the Lean benefits

Generally, to implement Lean, companies apply the five principles of Lean. Table 2 contains a set of Lean applications where the steps followed by its authors have been described separately for each one. Generally, they follow these 5 lean principles or they try to adapt them to their situations, requirements and needs.

The literature also includes several models and frameworks that can be adopted in order to implement Lean thinking, Manotas Duque and Riviera Cadavid (Diego Fernando and Rivera Cadavid, 2007) as examples have proposed these steps:

- Change planning (defining the need for change, senior management commitment and support, identifying target areas, model lines and outreach strategy)

- Implementation (eliminating waste, continuous improvement, continuous and pull systems, multi-functional teams, information systems)

- Measurement of progress

- Measures objective (monitoring the Lean implementation progress, continuous monitoring, benchmarking) 
Table 2 - Lean Implementation in the Literature

\begin{tabular}{|c|c|c|}
\hline Types of industries & Authors & Steps followed for the Lean implementation \\
\hline $\begin{array}{l}\mathrm{CNC} \\
\text { Manufacturing }\end{array}$ & $\begin{array}{l}\text { Verma and Sharma } \\
(2017)\end{array}$ & $\begin{array}{l}\text { - Mapping the current state and its analysis } \\
\text { - Creating the Future State Map } \\
\text { - Data analysis for each process and analysis of the future } \\
\text { flow map } \\
\text { - Identifying bottlenecks }\end{array}$ \\
\hline Furniture industry & Guner Goren (2017) & $\begin{array}{l}\text { - Mapping the current cartography } \\
\text { - Mapping the future mapping based on the detected Mudas } \\
\text { - Use continuous flow where possible } \\
\text { - Use supermarkets where continuous flow is impossible } \\
\text { - Build a FIFO line where there are varieties of products }\end{array}$ \\
\hline $\begin{array}{l}\text { Auto parts } \\
\text { manufacturing }\end{array}$ & $\begin{array}{l}\text { Dhiravidamani et al. } \\
(2018)\end{array}$ & $\begin{array}{l}\text { The authors implemented the techniques of Kobetsu-Kaizen } \\
\text { and the VSM. They were based on kaizen events according } \\
\text { to these steps: } \\
\text { - Team training } \\
\text { - Ensures management commitment and support } \\
\text { - Consider environmental measures as well as Lean } \\
\text { measures } \\
\text { - Identify environmental waste in Lean training } \\
\text { - Visualize environmental wastes and eliminate them } \\
\text { - Pursue and maintain efforts }\end{array}$ \\
\hline $\begin{array}{l}\text { Gearbox } \\
\text { Manufacturing }\end{array}$ & $\begin{array}{l}\text { Saravanan, } \\
\text { Nallusamy and } \\
\text { George (2018) }\end{array}$ & $\begin{array}{l}\text { The implementation is carried out by following a set of } \\
\text { steps in a flowchart prepared by the authors which includes } \\
\text { these steps: } \\
\text { - Existing study and problem identification } \\
\text { - Process study and observation } \\
\text { - Data collection, VSM and VA, NVA, and NNVA } \\
\text { identification } \\
\text { - Future state VSM } \\
\text { - Work standardization } \\
\text { - Results }\end{array}$ \\
\hline $\begin{array}{l}\text { Cable } \\
\text { manufacturing }\end{array}$ & $\begin{array}{l}\text { Chanarungruengkij } \\
\text { in Kaitwanidvilai } \\
(2018)\end{array}$ & $\begin{array}{l}\text { Based on the steps introduced in the "Lean way" book for } \\
\text { process improvement, which are: } \\
\text { - Visit the production site to check the current state of the } \\
\text { production line, identify and implement the process for } \\
\text { each stage, identify production wastage and map value } \\
\text { flows } \\
\text { - Improve the process by reducing waste } \\
\text { - Establish the future value stream mapping } \\
\text { - Summarize the results }\end{array}$ \\
\hline Automotive plant & $\begin{array}{l}\text { Pérez-Pucheta et al. } \\
(2019)\end{array}$ & $\begin{array}{l}\text { - Problem Statement } \\
\text { - Evolution of the current state } \\
\text { - Waste identification } \\
\text { - Development of future mapping } \\
\text { - Report on Proposal A3 }\end{array}$ \\
\hline
\end{tabular}




\begin{tabular}{|c|c|c|}
\hline Types of industries & Authors & Steps followed for the Lean implementation \\
\hline $\begin{array}{l}\text { Water heater } \\
\text { manufacturing }\end{array}$ & $\begin{array}{l}\text { Ur Rehman et al. } \\
(2020)\end{array}$ & $\begin{array}{l}\text { The steps of the adopted approach are as follows: } \\
\text { - Start } \\
\text { - Data collection (time study, performance history, demand } \\
\text { and production, shutdown history) } \\
\text { - Current state analysis (bottleneck study, flow and } \\
\text { distance map, availability and utilization, productivity } \\
\text { measurement, value stream map) } \\
\text { - Suggested improvements to remove detected problems } \\
\text { - Future state analysis (productivity analysis, value stream } \\
\text { map) } \\
\text { - Analysis of States (current and future) } \\
\text { - End }\end{array}$ \\
\hline $\begin{array}{l}\text { Agricultural } \\
\text { equipment } \\
\text { manufacturing }\end{array}$ & $\begin{array}{l}\text { Ramakrishnan et al. } \\
(2019)\end{array}$ & $\begin{array}{l}\text { The implementation of Lean practices was carried out in } \\
\text { nine units using the following steps: } \\
\text { - Diagnose the current level of these units - capture current } \\
\text { conditions and levels of Lean adherence using Lean } \\
\text { assessment tools } \\
\text { - Set objectives/steps include unit-specific projects and } \\
\text { joint projects to be undertaken } \\
\text { - Detailed list of projects and milestone-based objectives } \\
\text { for all units for activities in each phase } \\
\text { - General action plan for subsequent phases } \\
\text { - Formulation of a review mechanism to monitor progress } \\
\text { and targeted milestones }\end{array}$ \\
\hline
\end{tabular}

As the above table shows, the authors try to find the best practices to implement Lean Manufacturing somehow, But the aim of maximizing value and reducing waste is still unchanged.

\subsection{DMAIC Concept}

DMAIC is inspired by Deming practices and the Plan, Do, Check, and Act (PDCA) Cycle (Gupta, 2013), a systematic approach used to guide the scheduling and execution of Six Sigma projects. It is considered one of the essential and distinctive approaches for leading Six Sigma projects in process improvement and quality (Jirasukprasert et al., 2014). DMAIC is the acronym for the 5 steps that are Define, Measure, Analyze, Improve and Control (see Figure 2).

However, DMAIC can be operated without making reference to the six sigma approach. Reference (Dossou and Dedeban, 2017) the DMAIC cycle was exploited to improve the supply chain and in another reference (Popov et al., 2018) to analyze the root causes of circuit breaker failure in a distribution system.

The literature also reveals the integration of DMAIC with other approaches, such as with the VIKOR method (Zhou et al., 2018) or with the VSM tool (Guo et al., 2019). Furthermore, we can also find when DMAIC combines several approaches and methodologies, such as the DMAIC + approach (Sahay, Ghosh 
and Bheemarthi, 2011) which combine Lean manufacturing, six sigma and constraint theory.

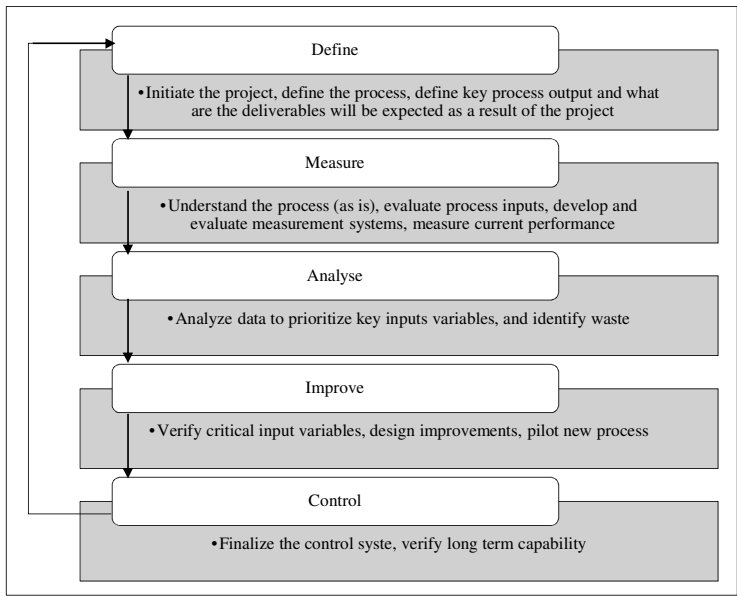

Figure 2 - The 5 Steps Of The DMAIC Cycle (Improta et al., 2017)

In this context where Lean can also be implemented through the deployment of the DMAIC approach, reference (Ferreira et al., 2019) where the authors presented a framework called "iLeanDMAIC" based on Lean tools and following the steps of the DMAIC approach, this iLeanDMAIC framework was validated by a case study in industry.

Our case study will also provide evidence of the successful implementation of Lean via DMAIC, especially since this approach ensures rigorous problem resolution and effectively manages process improvement actions.

\section{COMPANY BACKGROUND - REASONS FOR IMPLEMENTING LEAN MANUFACTURING}

In a context of hard competitiveness and quasi-permanent innovation, the host group has succeeded to become a leader in manufacturing metal components for the automotive industry in Europe. This group has 26 factories in eight countries (France, Spain, Czech Republic, Germany, Great Britain, Italy, Turkey, Morocco 
and China). The Moroccan site on which this case study was conducted is employing a staff of 431 people and deals with large companies such as Renault, Toyota, Audi, Valeo, Nissan, Seat, Volvo, Faurecia, Infinity, Volkswagen and others. This site supplies these companies with products made through several processes of cutting and stamping of metal parts, assembly parts, and profiling to manufacture structural parts, substructures, openings, and mechanical parts (engine components).

The Lean was implemented with the aim of improving the physical flow between a site press and the assembly stations (Figure 3 ). The project team realized that Lean Manufacturing is the best solution for identifying non-value-added activities and improving flows, as long as the company seeks to eliminate the different waste forms within the workshop. In order to succeed in this project our multi-skilled team was accompanied by consultants from Kaizen Institute who participated in the different stages of the application and solutions validation.

\section{LEAN IMPLEMENTATION FRAMEWORK: CASE STUDY}

In this case study, the DMAIC problem solving methodology was chosen to implement Lean Manufacturing, where its tools will be deployed in each DMAIC approach phase. This choice is supported by the project team due to the structured steps that DMAIC provides, which will facilitate the waste source extraction in the shop floor which is the main objective of the project.

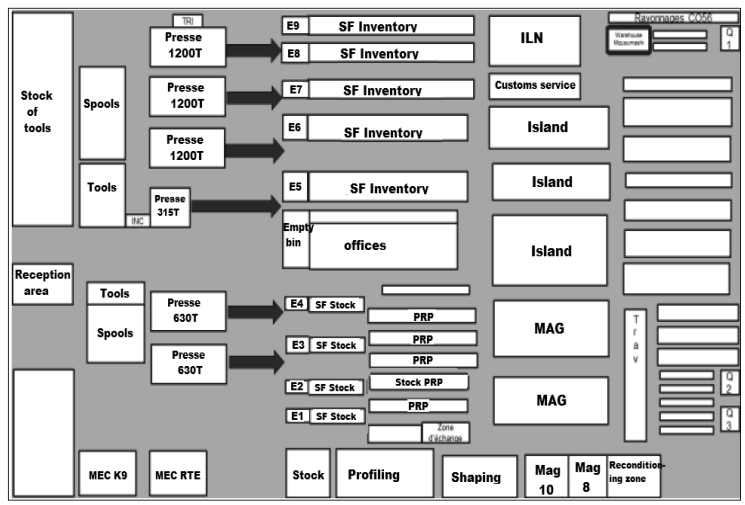

Figure 3 - Factory Plan 
The materials that flow in the plant are a cellular flow. That means that each press produces according to its proper production program developed following MRP planning, which is independent of the other machines. The items or references produced are either shipped directly or placed in semi-finished SF inventory for a long time period, which can vary from 6 to 26 days or more, before proceeding to other operations

\subsection{Define Phase}

The definition phase consists of defining the Lean project objectives and selecting high-impact improvement opportunities. But before visiting the site and defining the processes and their elements, project team need to validate the following:

- The commitment of top management

- The impact assessment of the implementation

- The training of all team members

- The definition of the team/project charter

During the team formation, the resource availability constraint imposed the creation of the RACI matrix to assign responsibilities to the different work team members. Furthermore, in order to successfully implement Lean in this production site, some objectives were set as follows:

- Fluidity and computerize the physical flow

- Reconfigure production lines for linear flow via Kanban-pulled flow instead of cellular and MRP-pulled flow

- Eliminate non-value added activities

- Deploying Lean and Mizusumashi tools for flow improvement

- Eliminate the root causes of waste generation

- Transformation of the SF stock from flat stock to shelf stock (less stock space)

\subsection{Measure Phase}

In our case, the majority of the products that encountered more waste are the semi-finished products performed on the $315 \mathrm{~T}$ press, these SF products are either to be reconditioned in the workstations, or sent to a re-conditioning area to be delivered to the workstations.

In order to better visualize the current situation and determine the problems and waste sources, we developed a physical flow mapping of a model reference (see Figure 4), where the different qualitative and quantitative characteristics of the physical flow collected from the site were introduced. 
The reference choice was carried out through a meeting with the Lean team which selected the reference 106,234PC (Secondary Flask D Traverse X52), regarding the problems it presents to the production operators and the complexity of its flow. The same goes for the $315 \mathrm{~T}$ press, limited to operations with very low added value and a significant WIP level, and other problems that will be dealt with in the remaining DMAIC phases.

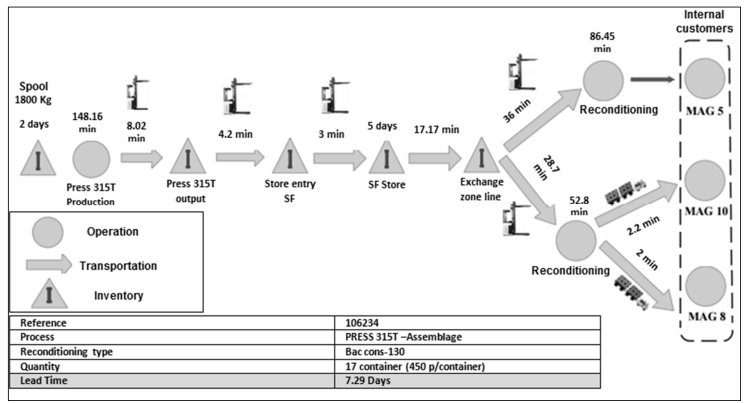

Figure 4-Current Situation Mapping

The realization of a flowchart which describes the process under a time notation and the process steps in a simple way while classifying them by categories (operation, control, transport, delay, storage) showed that the majority of the time is a storage time resulting in an increased lead time of 7.29 days. This lead time led the team to calculate the speed of the $315 \mathrm{~T}$ press in order to compare it with the takt time for each article where the result showed a huge gap between the two (see Figure 5). For example, for part number 82275 EQUERPC, the customer requests one part every $656 \mathrm{~s}$, and the factory supplies one part every $14.81 \mathrm{~s}$. The customer request is respected but the storage time and the quantity stored is very important, which generates additional costs for the company as it adopts the MRP push-flow production management. 


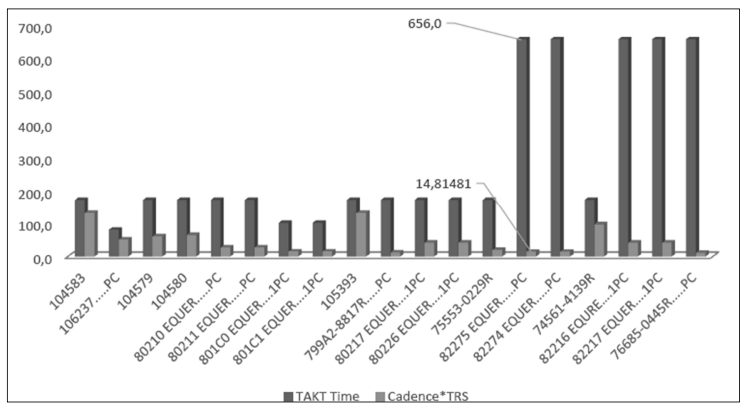

Figure 5 - Comparison of Rate and Customer Takt Time

To better visualize all the movements and displacements within the workshop, the realization of a spaghetti diagram appeared an essential step to avoid this type of waste. Figure 6 presents the spaghetti diagram of the workshop showing the physical flow that links the $315 \mathrm{~T}$ press, the inventory and the assembly stations.

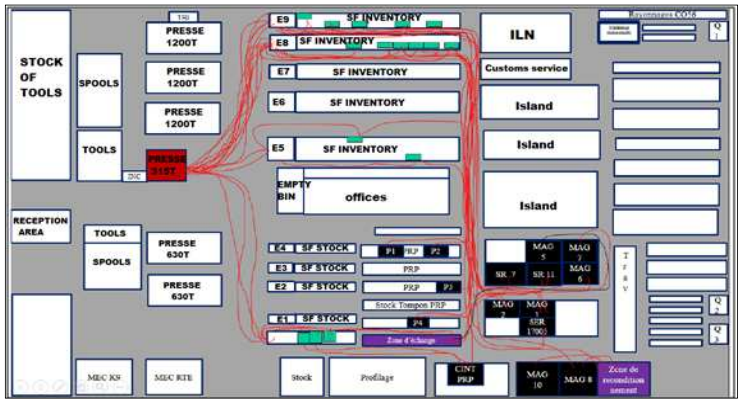

Figure 6-Spaghetti Diagrams

This diagram will contribute to the efficiency improvement and the reduction of employee fatigue due to unnecessary movements as well as the minimization of energy consumption for forklift operators travelling longer distances. 


\subsection{Analyze Phase}

The main objective of this phase is to analyze the results found in the previous phase in order to treat and highlight the root causes which will allow the optimal solutions to be generated. For the $315 \mathrm{~T}$ press, it encounters several types of wastage where Table 3 shows the most dominant wastes.

\section{Table 3 - 315T Press Waste}

\begin{tabular}{|l|l|}
\hline Waste type & Description \\
\hline Movement Muda & $\begin{array}{l}\text { The spaghetti diagram shows the complexity of the flow between the 315T press, the } \\
\text { stock and the assembly stations. The diversity of SF parts forces the forklift drivers } \\
\text { to circulate too much to supply each station with the necessary quantity. However, } \\
\text { these movements follow no standard, which generates unnecessary movements that } \\
\text { can lead to production stoppages and require a significant loading time for the } \\
\text { drivers. }\end{array}$ \\
\hline $\begin{array}{l}\text { Over-processing } \\
\text { muda }\end{array}$ & $\begin{array}{l}\text { According to Figure 4, there are some operations that take a considerable time and } \\
\text { do not bring any added value for the customer. } \\
\text { As an example, the reconditioning of SF parts in large plastic or metal bins, for } \\
\text { which a non-value added time of 41.18 hours has been calculated which must be } \\
\text { minimized (This time is the sum of the reconditioning times per month for all } \\
\text { references) Adding that the reconditioning conditions do not respect the rules of } \\
\text { ergonomics at work. }\end{array}$ \\
\hline Storage Muda & $\begin{array}{l}\text { SF parts remain in stock for } 5 \text { days on average, for this reason the delivery time } \\
\text { takes more than 7 days. Although the tools in the workshop have been organized } \\
\text { according to the duration and the occupied storage area, it is necessary to minimize } \\
\text { the size of these tools and taking into account the safety factor during use. } \\
\text { Another study of calculation of occupied surface showed that the storage surface } \\
\text { dedicated by the 19 references is } 28.43 \text { m², which is equivalent to 32 locations that } \\
\text { must be minimized. }\end{array}$ \\
\hline Other Muda & $\begin{array}{l}\text { The 315T press meets many problems with forklift trucks in terms of efficiency, loss } \\
\text { of time and cost for maintenance operations and production stoppages. In addition, } \\
\text { as the company wants to re-experience the Mizusumashi train and try to create a } \\
\text { PULL system to achieve the Just in Time. }\end{array}$ \\
\hline
\end{tabular}

\subsection{Improve Phase}

Figure 7 shows the new workshop configuration containing the Lean Manufacturing guidelines. The modifications illustrated in this improved model are:

- The implementation of the Kanban method for a pull flow

- The creation of a supermarket at the $315 \mathrm{~T}$ press output for semi-finished parts (SF)

- The reduction of batch size transfer through the implementation of sustainable packaging

- The implementation of the Mizusumashi solution 
- The use of the A3 to provide a global and complete vision of the problem and the solutions implemented step by step, including the final results obtained as well as the resources required to achieve these results

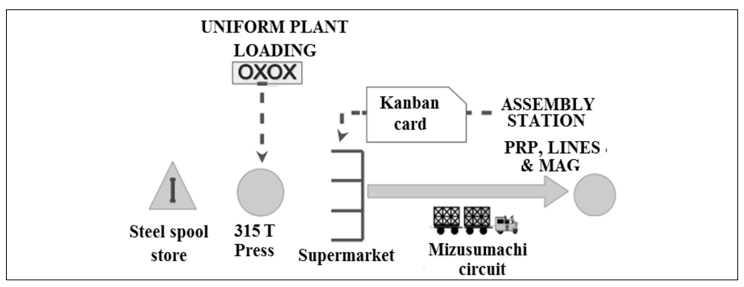

Figure 7 - The New Configuration of the 315T Press

Supermarket implantation: Before implanting the supermarket, the team carried out several calculations and examined the existing constraints, for example calculating the maximum launch sizes of each reference by considering the following parameters:

- Annual customer requirement (Sales and Operations Planning SOP) for each project

- Reference assignment within the projects

- Nomenclature coefficient

- Tool categories

It was necessary to calculate the maximum space that can be exploited with an adequate design. Figure 8 shows the market design in 3D on CatiaV5, it is a dynamic supermarket with two levels, one for full bins in front of the picking zone which is the loading area via the Mizusumashi, and another level for empty bins in the opposite direction of the $315 \mathrm{~T}$ press. 


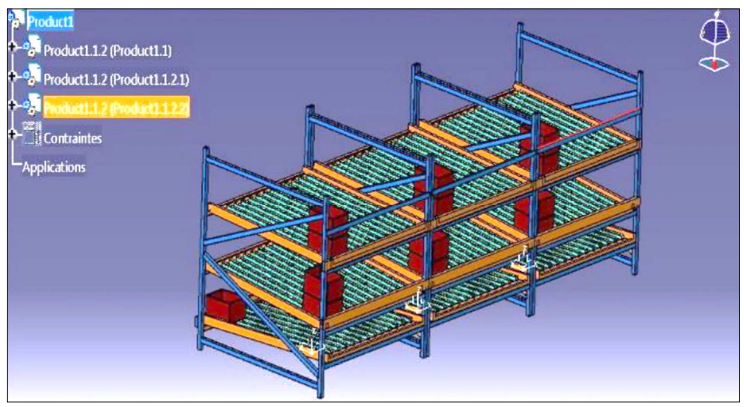

Figure 8-The 3D Supermarket by CATIA V5

Production leveling - Heijunka: In this case, the team decided to apply the load levelling for the following reasons:

- Insufficient space to install the supermarket on the edge of the $315 \mathrm{~T}$ press line, due to the batch size, which may require a storage time exceeding three weeks

- Takt time of the company is smaller than that of the customer

- Heijunka is one of the pillars of the Lean Temple

For this reason, it was necessary to validate the internal constraints such as the tool maintenance constraint, the average maintenance constraint, the serial method constraint and finally the logistic constraint. This validation allows suggesting a scenario that acts on all the tool classes in order to reduce the launch sizes. Table 4 shows a comparison between the old and new production schedule following the levelling of the production. This new program will maintain a high efficiency of the pull system.

The available capacity of the supermarket is only 720 bins, due to the Heijunka, the need for Odette boxes has decreased from 1,952 to 696 bins, which is very opportune. 
Table 4 - Old Vs. New Production Planning

\begin{tabular}{|c|c|c|c|c|c|c|c|c|}
\hline \multirow{2}{*}{$\begin{array}{l}\text { Items } \\
\text { reference }\end{array}$} & \multirow{2}{*}{$\begin{array}{l}\text { Net requirement } / \\
\text { production launch }\end{array}$} & \multicolumn{7}{|c|}{ Planning without Production Leveling (Heijunka) } \\
\hline & & Week 1 & Week 2 & Week 3 & Week 4 & Week 5 & Week 6 & Total \\
\hline 104583 & 18159 & & & & & & & \\
\hline 106237 & 37122 & & & & & & & \\
\hline \multirow[t]{3}{*}{105393} & 19980 & & & & & & & \\
\hline & & \multicolumn{7}{|c|}{ Planning with Production Leveling (Heijunka) } \\
\hline & & Week 1 & Week 2 & Week 3 & Week 4 & Week 5 & Week 6 & Total \\
\hline 104583 & 4540 & & & & & & & 18159 \\
\hline 106237 & 99281 & & & & & & & 37122 \\
\hline 105393 & 9990 & & & & & & & 19980 \\
\hline
\end{tabular}

Mizusumashi train (water spider): The Mizusumashi train has already been adopted in another site of the group, which has shown its effectiveness and still encouraged to implement it in this project, among the advantages it will lead, we can find:

- An improved flow by eliminating stoppages due to lack of production parts

- Avoiding the creation of work-in-process inventory

- Elimination of non-value added activities

- Delivery of lines with a $100 \%$ service rate ( 0 production stoppages due to missing parts)

- Reduction of waste due to unnecessary movement and transportation

Before starting to use the train, a set of standards have been established to improve performance and take into consideration internal safety rules, battery change rate and circuit control. These elements were addressed in work instructions in addition to audits in order to validate the solution. Figure 9 shows the new spaghetti diagram with the optimized train route and the supermarket positioning. 


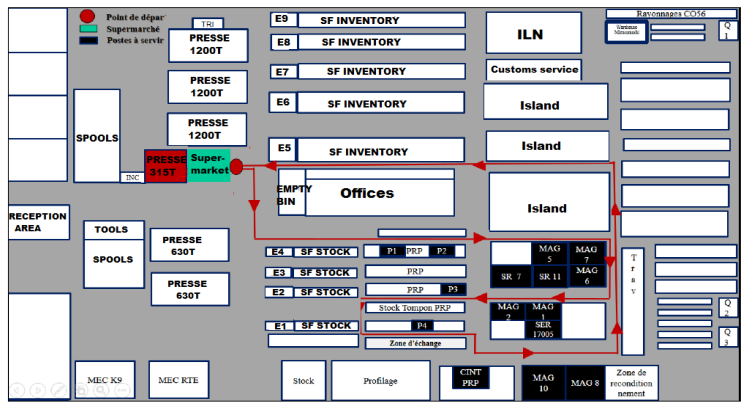

Figure 9 - The Mizusumashi Train Route

Kanban: The first improvement actions facilitated the Kanban implementation, before its implementation the team worked on the Kanban card design and the card needs for all the references. For the operating principle in the workshop, when the operator starts consuming the bins, he takes the Kanban cards from the bins and places them on the support of the SPS table, the driver of the Mizusumashi train collects the cards and empty bins and then returns to the supermarket to put the empty bins in their place. As a second action he takes the bins filled with the references of each Kanban card to deliver them to the stations during the next cycle (see Figure 10).

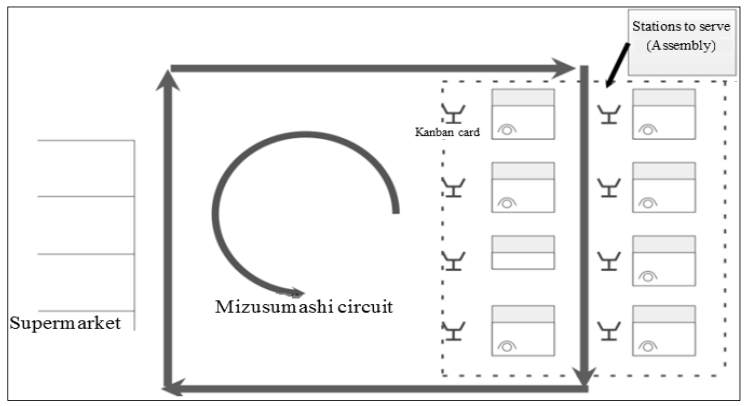

Figure 10 - The New Workshop Configuration for the 315 T Press 
Visual Management: several actions have been carried out within the visual management context in order to improve flow control and minimize waste related to movements and transportation. The team also proposed the realization of A3 thinking for a better project presentation for other departments and maintaining actions to avoid the occurrence of other types of waste (see Figure 11).

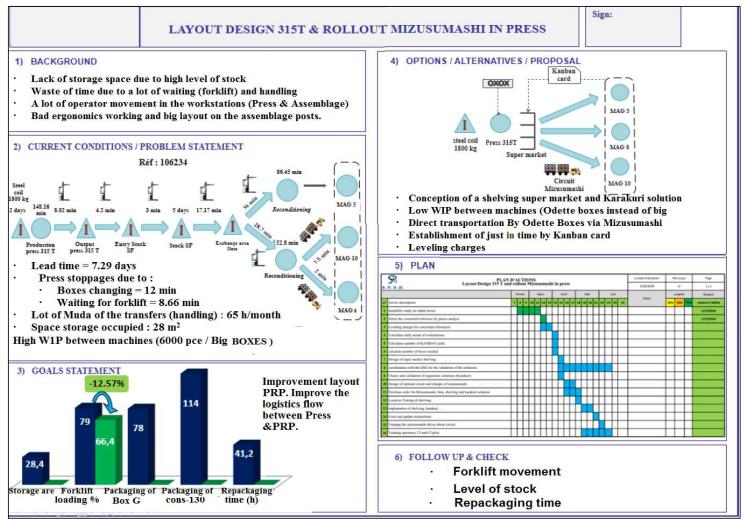

Figure $11-A 3$ Thinking

\subsection{Control Phase}

In order to control and monitor the different implementation stages of the project, the relevance of the solutions and to ensure the expected results, several audits and actions have been planned and carried out:

- An audit of all the actions performed;

- A Kanban start-up audit: This audit is performed as a flash audit where a set of anomalies are provided after an in-depth brainstorming. These anomalies include: lack of Kanban ticket, Component rupture, incorrect location of Bac Odette, etc. This flash audit will evaluate the conformity of the different requirements fixed to achieve a pulled and continuous flow, at the same time through this audit the company can detect other improvement opportunities;

- A verification and control of the new press load has been achieved to be sure that the load is adapted to the new modifications (the calculated rate is $92 \%$, which implies that there is no problem during production); 
- An audit on the respect of the Mizusumashi train rules: a set of instructions, rules and penalties have been prescribed to maintain the proper functioning of the train and to guarantee the safety of the operators, especially since this train circulates permanently in the workshop to supply the necessary components to the stations and to recuperate the finished or semi-finished parts. Among the rules that have been established in the instructions and audit sheet we find: the respect of the circuit traced for the train, the respect of the highest speed which must not exceed $(15 \mathrm{~km})$ by the train, the decrease of the speed to the minimal $(5 \mathrm{~km} / \mathrm{h})$ in the intersections and the corridors accesses, the stationing of Mizusumashi at the detected place, etc.

\section{EFFECTIVENESS OF THE LEAN MANUFACTURING APPLICATION}

The team has evaluated the financial benefits for each solution and for the industrial break-even point it corresponds to the investment recovery period: Break-even point $=$ investment / savings per unit of time.

In this case, since the project was completed, the company obtained an immediate gain of $39,5013 \mathrm{DH}$ (gain on packaging and storage cost), which covered the investment of 22,2009.2 DH (Supermarket and Bac Odette) (see Table 5), adding a gain of $17,3003.8 \mathrm{DH}$ and a monthly sum of 2,7937.36 $\mathrm{DH}$ related to the handling equipment rented at $2860 /$ month, gain of the reconditioning time of 2,560 DH/month (gain of 41.18 hours) and gain on the rental price of the storage areas of $2,2516.56 \mathrm{DH}$ (rental price of the square meter in the free zone is $792 \mathrm{dh} /$ month) where Table 6.

Table 5 - Total Cost of Solutions

\begin{tabular}{|l|c|}
\hline Solution & Cost \\
\hline Bac Odette & $53,209.2 \mathrm{DH}$ \\
\hline Supermarket purchase & $168,800 \mathrm{DH}$ \\
\hline Total & $222,009.2 \mathrm{DH}$ \\
\hline
\end{tabular}

Table 6 - Cost Savings for Each Solution

\begin{tabular}{|l|c|}
\hline Solution & Saving \\
\hline Storage Surface (a monthly gain) & $22,516.56 \mathrm{DH}$ \\
\hline Packaging & $141,491 \mathrm{DH}$ \\
\hline Handling equipment (a monthly gain) & $2,860 \mathrm{DH}$ \\
\hline Packaging & $141,491 \mathrm{DH}$ \\
\hline Storage Cost & $200,313 \mathrm{DH}$ \\
\hline
\end{tabular}




\section{CONCLUSION}

This paper provides a specific and practical application of Lean Manufacturing following the DMAIC approach, this concept that is generally linked to six sigma applications. Despite the different application frameworks of Lean, the proposal to implement a lean project following the DMAIC model offered some advantages that were not available in comparison with others, such as the structuring of the application steps and especially at the analytical phase, which allowed the correct analysis of the problems and the best choice of tools to apply.

In each phase of the DMAIC cycle a large number of Lean tools were used like kaizen, Gemba walking, Heijunka, Kanban, Mizusumashi, Visual Management and spaghetti diagram which allowed:

- A reduction in turnaround time with $21 \%$

- A reduction of $90 \%$ in WIPs

- A gain of $28.43 \mathrm{~m}^{2}$ of storage space

- A reduction in forklift load by $13 \%$

- An Increase in the installations' safety level by eliminating stock pillars and reducing forklift traffic

- The Kanban, Heijunka and the Mizusumashi train have streamlined the flow in the workshop, contributed to the inventory reduction and the human and industrial capacity optimization

These solutions have generated a gain of 39,5013 DH (gain in packaging and storage cost), which largely covers the investment of 22,2009.2 DH (Supermarket and Bac Odette), as well as benefiting from a monthly gain of 27,937.36 DH/month.

After this implementation of Lean Manufacturing, the company planned to computerize the Kanban information, this solution will allow better real-time production visualization and this change will allow the main customer RENAULT to follow the production of its articles in real time as well as its orders.

To conclude, the most recognized framework in the literature for the Lean implementation is following the 5 principles especially that this framework focuses on the value in each step, but the particularity and the advantage of the DMAIC concept is the project structuring which allowed all team members to observe and follow the implementation progress.

For the research perspectives, a quantitative study is envisaged to unveil the Lean implementation mode in the Moroccan industry and specifically the automotive industry as well as the barriers and obstacles to the success of the lean project. In addition, a quantitative study will be conducted to verify the link between the 
implementation of Lean and the social and environmental dimensions in the Moroccan industry.

\section{REFERENCES}

Andersson, R., Eriksson, H. and Torstensson, H., 2006. Similarities and differences between TQM, six sigma and lean. The TQM Magazine, [e-journal] 18(3), pp.282-296.DOI: 10.1108/09544780610660004.

Balzer, W.K., Francis, D.E., Krehbiel, T.C. and Shea, N., 2016. A review and perspective on Lean in higher education. Quality Assurance in Education, [e-journal] 24(4), pp.442-462.DOI: 10.1108/QAE-03-2015-0011.

Chanarungruengkij, V. and Kaitwanidvilai, S., 2018. An Application of Lean Automation: A Case Study of Thailand's Control Cable Manufacturing. In: IEEE (International Electrical Engineering Congress iEECON), 2018 International Electrical Engineering Congress (iEECON). Krabi, Thailand, 7-9 March 2018. IEEE. pp.1-4. DOI: 10.1109/IEECON.2018.8712287.

Ching, N.T, Hoe, C., Hong, T., Ghobakhloo, M. and Pin, C., 2015. Case study of lean manufacturing application in a die casting manufacturing company. In: A. Bansil, G. Venuri and A. Postnikov, eds., Proceedings of the International Conference on Condensed Matter Physics 2014 (ICCMP 2014). Shimla, India, 4-6 Nov. 2014. AIP Publishing. DOI: 10.1063/1.4915851.

Dhiravidamani, P., Ramkumar, A.S., Ponnambalam, S.G. and Subramanian, N., 2018. Implementation of lean manufacturing and lean audit system in an auto parts manufacturing industry - an industrial case study. International Journal of Computer Integrated Manufacturing, [e-journal] 31(6), pp.579-594. DOI: 10.1080/0951192X.2017.1356473.

Diego Fernando, M.D. and Rivera Cadavid, L., 2007. Lean manufacturing measurement: the relationship between lean activities and lean metrics. Estudios Gerenciales, [e-journal] 23(105), pp.69-83. DOI: $10.1016 / \mathrm{S} 0123-5923(07) 70026-8$.

Dossou, P.E. and Dedeban, G., 2017. Using DMAIC for Making Sustainable Supply Chain Efficient in a GRAI Environment. In: P. Golinska-Dawson and A. Kolinski, eds. 2017. Efficiency in Sustainable Supply Chain. Cham: Springer International Publishing. pp.63-85. DOI: 10.1007/978-3-319-46451-0_5.

Ferreira, C., Sá, J.C., Ferreira, L.P., Lopes, M.P., Pereira, T., Ferreira, L.P. and Silva, F.J.G., 2019. iLeanDMAIC - A methodology for implementing the lean tools. Procedia Manufacturing, [e-journal] 41, pp.1095-1102. DOI: 10.1016/j.promfg.2019.10.038. 
Guner Goren, H., 2017. Value stream mapping and simulation for lean manufacturing: A case study in furniture industry. Pamukkale University Journal of Engineering Sciences, [e-journal] 23(4), pp.462-469. DOI: 10.5505/pajes.2016.59251.

Guo, W., Jiang, P., Xu, L. and Peng, G., 2019.Integration of value stream mapping with DMAIC for concurrent Lean-Kaizen: A case study on an airconditioner assembly line. Advances in Mechanical Engineering, [e-journal] 11(2), p.168781401982711. DOI: 10.1177/1687814019827115.

Gupta, N., 2013. An Application of DMAIC Methodology for Increasing the Yarn Quality in Textile Industry. IOSR Journal of Mechanical and Civil Engineering, [e-journal] 6(1), pp.50-65. DOI: 10.9790/1684-0615065.

Hidayati, J., Tarigan, U.P.P. and Tarigan, U., 2019. Implementation of Lean Service to Reduce Lead Time and Non Value Added Activity in a Banking Institution. IOP Conference Series: Materials Science and Engineering, [e-journal] 505, p.012076. DOI: 10.1088/1757-899X/505/1/012076.

Improta, G., Balato, G., Romano, M., Ponsiglione, A.M., Raiola, E., Russo, M.A., Cuccaro, P., Santillo, L.C. and Cesarelli, M., 2017. Improving performances of the knee replacement surgery process by applying DMAIC principles. Journal of Evaluation in Clinical Practice, [e-journal] 23(6), pp.1401-1407. DOI: 10.1111/jep.12810.

Jerry, K., 2003. LEAN principles, Manufacturing extension partnership. Utah: Manufacturing Extension Partnership.

Jirasukprasert, P., Garza-Reyes, J.A., Kumae, V. and Lim, M.K., 2014. A Six Sigma and DMAIC application for the reduction of defects in a rubber gloves manufacturing process. International Journal of Lean Six Sigma, [e-journal] 5(1), pp.2-21. DOI: 10.1108/JJLSS-03-2013-0020.

Li, S., Fang, Y. and Wu, X., 2020.A systematic review of lean construction in Mainland China. Journal of Cleaner Production, [e-journal] 257, p.120581. DOI: 10.1016/j.jclepro.2020.120581.

Liker, J.K., 2004. The Toyota way: 14 management principles from the world's greatest manufacturer. New York: McGraw-Hill.

Marodin, G.A., Frank, A.G., Tortorella, G.L. and Fetterman, D.C., 2019. Lean production and operational performance in the Brazilian automotive supply chain. Total Quality Management \& Business Excellence, [e-journal] 30(3-4), pp.370-385. DOI: 10.1080/14783363.2017.1308221.

Mostafa, S., Chileshe, N. and Abdelhamid, T., 2016. Lean and agile integration within offsite construction using discrete event simulation: A systematic literature review. Construction Innovation, [e-journal] 16(4), pp.483-525. DOI: 10.1108/CI-09-2014-0043. 
Nguyen, M.-N. and Do, N.-H., 2016. Re-engineering Assembly Line with Lean Techniques. Procedia CIRP, [e-journal] 40, pp.590-595. DOI: 10.1016/j.procir.2016.01.139.

Pech, M. and Vaněček, D., 2018. Methods of Lean Production to Improve Quality in Manufacturing. Quality Innovation Prosperity, [e-journal] 22(2), p.1-15. DOI: 10.12776/qip.v22i2.1096.

Pérez-Pucheta, C.E., Olivares-Benitez, E., Minor-Popocatl, H., Pacheco-García, P.F. and Pérez-Pucheta, M.F., 2019. Implementation of Lean Manufacturing to Reduce the Delivery Time of a Replacement Part to Dealers: A Case Study. Applied Sciences, [e-journal] 9(18), p.3932. DOI: 10.3390/app9183932.

Piercy, N. and Rich, N., 2009. Lean transformation in the pure service environment: the case of the call service centre. International Journal of Operations \& Production Management, [e-journal] 29(1), pp.54-76. DOI: 10.1108/01443570910925361.

Popov, I., Jenner, D., Todeschini, G. and Igic, P., 2018. Use of the DMAIC Approach to Identify Root Cause of Circuit Breaker Failure. In: 2018 International Symposium on Power Electronics, Electrical Drives, Automation and Motion (SPEEDAM). Amalfi: IEEE. pp. 996-1001. DOI: 10.1109/SPEEDAM.2018.8445417.

Ramakrishnan, V., Jayaprakash, J., Elanchezhian, C. and Vijaya Ramnath, B., 2019. Implementation of Lean Manufacturing in Indian SMEs-A case study. Materials Today: Proceedings, [e-journal] 16(2), pp.1244-1250. DOI: 10.1016/j.matpr.2019.05.221.

Régis, T.K.O., Santos, L.C. and Gohr, C.F., 2019. A case-based methodology for lean implementation in hospital operations. Journal of Health Organization and Management, [e-journal] 33(6), pp.656-676. 10.1108/JHOM-09-2018-0267.

Rifqi, H., Ben Souda, S. and Zamma, A., 2020. Lean Maintenance 4.0: An application of the IoT Technology in the facility management industry. International Journal of Advanced Trends in Computer Science and Engineering, [e-journal] 9(5), pp.9064-9070. DOI: 10.30534/ijatcse/2020/311952020.

Rüttimann, B.G. and Stöckli, M.T., 2016. Going beyond Triviality: The Toyota Production System - Lean Manufacturing beyond Muda and Kaizen. Journal of Service Science and Management, [e-journal] 09(02), pp.140-149. DOI: 10.4236/jssm.2016.92018.

Sahay, C., Ghosh, S. and Bheemarthi, P.K., 2011. Process Improvement of Brake Lever Production Using DMAIC (+). In: ASME (The American Society of MEchanisal Engineers), Proceedings of the ASME 2011 International Mechanical Engineering Congress and Exposition. Volume 3: Design and Manufacturing. Denver, Colorado, Usa, 11-17 Nov. 2011. pp.801-826. USA: ASME. DOI: 10.1115/IMECE2011-63813. 
Salonitis, K. and Tsinopoulos, C., 2016. Drivers and Barriers of Lean Implementation in the Greek Manufacturing Sector. Procedia CIRP, [e-journal] 57, pp.189-194. DOI: 10.1016/j.procir.2016.11.033.

Saravanan, V., Nallusamy, S. and George, A., 2018. Efficiency Enhancement in a Medium Scale Gearbox Manufacturing Company through Different Lean Tools - A Case Study. International Journal of Engineering Research in Africa, [e-journal] 34, pp.128-138. DOI: 10.4028/www.scientific.net/JERA.34.128.

Sharma, S. and Gandhi, P.J., 2017. Scope and Impact of Implementing Lean Principles \& Practices in Shipbuilding. Procedia Engineering, [e-journal] 194, pp.232-240. DOI: 10.1016/j.proeng.2017.08.140.

Shingō, S. and Dillon, A.P., 1989. A study of the Toyota production system from an industrial engineering viewpoint. Rev. ed. Cambridge: Cambridge Mass Productivity Press.

Sieckmann, F., Ngoc, H.N., Helm, R. and Kohl, H., 2018. Implementation of lean production systems in small and medium-sized pharmaceutical enterprises. Procedia Manufacturing, [e-journal] 21, pp.814-821. DOI: 10.1016/j.promfg.2018.02.188.

Su, C.-T., Chiang, T.-L.and Chang, C.-M., 2006. Improving service quality by capitalising on an integrated Lean Six Sigma methodology. International Journal of Six Sigma and Competitive Advantage, [e-journal] 2(2), p.1-22. DOI: 10.1504/IJSSCA.2006.009367.

Ur Rehman, A., Usmani, Y.S., Umer, U. and Alkahtani, M., 2020. Lean Approach to Enhance Manufacturing Productivity: A Case Study of Saudi Arabian Factory. Arabian Journal for Science and Engineering, [e-journal] 45(3), pp.2263-2280. DOI: 10.1007/s13369-019-04277-9.

Vamsi Krishna Jasti, N. and Sharma, A., 2014. Lean manufacturing implementation using value stream mapping as a tool: A case study from auto components industry. International Journal of Lean Six Sigma, [e-journal] 5(1), pp.89-116. DOI: 10.1108/IJLSS-04-2012-0002.

Verma, N. and Sharma, V., 2017. Sustainable competitive advantage by implementing lean manufacturing "A Case study for Indian SME". Materials Today: Proceedings, [e-journal] 4(8), pp.9210-9217. DOI: 10.1016/j.matpr.2017.07.279.

Womack, J., Jones, D.T. and Roos, D., 1991.The machine that changed the world: the story of lean production -- Toyota's secret weapon in the global car wars that is revolutionizing world industry, undefined. [pdf] Semantic Scholar. Available at: <https://www.semanticscholar.org/paper/The-machine-thatchanged-the-world-\%3A-the-story-of-Womack-

Jones/4cac51c7ab0b49824feab0b5645b22eb22b378e5>

[Accessed 26 August 2020]. 
Wronka, A., 2017. Lean Logistics. Journal of Positive Management, [e-journal] 7(2), p.55. DOI: 10.12775/JPM.2016.012.

Zhou, F., Wang X., Lim M.K. and Liu, Y., 2018. Quality Improvement Practice Using a VIKOR-DMAIC Approach: Parking Brake Case in a Chinese Domestic Auto-Factory. In: S. Wang, M. Price, M. Lim, Y. Jin, Y. Luo and R. Chen, eds. Recent Advances in Intelligent Manufacturing. ICSEE 2018, IMIOT 2018. Singapore: Springer Singapore. pp.157-168. DOI: $10.1007 / 978-981-13-2396-6 \_14$.

\begin{abstract}
ABOUT AUTHORS
Hanane Rifqi ${ }^{0000-0001-8792-8343}$ (H.R.) - Laboratory of Signals, Distributed Systems and Artificial Intelligence SSDIA of the Higher Normal School of Technical Education ENSET, Hassan II University Casablanca, Morocco, Ph.D. Candidate in the field of industrial engineering, e-mail: hanane.rifqi.14@gmail.com.
\end{abstract}

\begin{abstract}
Abdellah Zamma $0000-0002-0390-4158$ (A.Z.) - Laboratory of Signals, Distributed Systems and Artificial Intelligence SSDIA of the Higher Normal School of Technical Education ENSET, Hassan II University Casablanca, Morocco, Prof., e-mail: zamma@enset-media.ac.ma.
\end{abstract}

Souad Ben Souda ${ }^{0000-0002-4378-3602}$ (S.B.S.) - Laboratory of Signals, Distributed Systems and Artificial Intelligence SSDIA of the Higher Normal School of Technical Education ENSET, Hassan II University Casablanca, Morocco, Prof., e-mail: souadbensou@hotmail.com.

Mohamed Hansali ${ }^{0000-0001-9726-4018}$ (M.H.) - Department of economics and management, Hassan II University Casablanca, Morocco, Ph.D., e-mail: hansali.mohamed1@gmail.com.

\title{
AUTHOR CONTRIBUTIONS
}

Conceptualization, H.R.; Methodology, H.R.; Validation, S.B.S. and A.Z.; Formal analysis, M.H.; Original draft preparation, H.R.; Review and editing, H.R.; Visualization, M.H., S.B.S., and A.Z.; Supervision, A.Z.

\section{CONFLICTS OF INTEREST}

The authors declare no conflict of interest. The funders had no role in the design of the study; in the collection, analyses, or interpretation of data; in the writing of the manuscript, or in the decision to publish the results. 